\begin{tabular}{|c|c|c|}
\hline PORT SAID ENGINEERING RESEARCH JOURNAL \\
Faculty of Engineering - Port Said University \\
Volume (21) No. (2) September 2017 pp. 103:110
\end{tabular}

\title{
Simulation of nitrate distribution under different drip irrigation systems
}

\author{
Romysaa Elasbah ${ }^{1}$, Tarek Selim², and Ahmed Mirdan ${ }^{3}$
}

\begin{abstract}
In this study, the HYDRUS-2D/3D was used to simulate nitrate distribution within the soil under surface drip irrigation (DI) and subsurface drip irrigation (SDI) with emitter at depths 10 and $20 \mathrm{~cm}$ for tomato crop. Three different soil types (sand, loamy sand, and sandy loam) were considered. Also, the influence of initial soil moisture content on nitrate distribution, leaching out from simulation domain, and uptake by plant roots were investigated. Results showed that the highest percentage of nitrate leaching out from the simulation domain was occurred in sandy soil under the SDI with emitter at depth $20 \mathrm{~cm}$ as compared to other irrigation systems. It was about 5\% under SDI with $20 \mathrm{~cm}$ emitter depth while approximately no leaching was occurred under other irrigation systems. The SDI with shallow emitter depth had the lowest percentage of nitrate leaching out from the simulation domain and the highest nitrate uptake by plant roots. As nitrate is effectively taken up by the plant roots, this will lead to reducing the groundwater contamination risk. Results also showed higher initial soil moisture content leads to augment in the percentage of nitrate leaching out from the simulation domain. Therefore, monitoring of the initial soil moisture content can lead to a good estimation of the nitrate leached to deeper soil layers and the potential of groundwater contamination risk.
\end{abstract}

Keywords: Drip irrigation, nitrate distribution, initial soil moisture content, HYDRUS-2D/3D.

\section{INTRODUCTION}

Drip irrigation system permits the application of small amounts of water regularly at a small volume of soil with low application rate and high frequency to reduce nutrient leaching [9]. Fertigation can be defined as the operation of mixing irrigation water with fertilizer. The application of fertilizer through the drip irrigation is called drip fertigation.Through drip fertigation, nutrients can effectively deliver to the plant roots zone at the required concentrations [3, 5, 12]. However, excessive application of fertilizer can increase the potential of groundwater contamination risk. The amount and intensity of precipitation, the fertilizer uptake capacity of the plant roots, and the ability of irrigation system tomanage drainage and leaching are also other factors affect on the potential of

${ }^{1}$ Civil Engineering Department, Faculty of Engineering, Port Said University, Port Said, Egypt, E-mail: eng.romysaa@yahoo.com

${ }^{2}$ Civil Engineering Department, Faculty of Engineering, Port Said University, Port Said, Egypt, E-mail: eng_tarek_selim@yahoo.com

${ }^{3}$ Civil Engineering Department, Faculty of Engineering, Port Said University, Port Said, Egypt, E-mail: a_mirdan@yahoo.com groundwater contamination risk. Thus, detailed knowledge of water and fertilizer distribution patterns in the root zone, their availability in the vicinity ofthe roots, and fertilizer leaching below the roots zone are required for the proper design of drip fertigation systems [13].

For Egyptian agricultural circumstances, nitrogen is considered one of the key factors in crop production [10]. Due to its intemperate use, nitrate concentrations in the ground water increased. Thus, appropriate design of irrigation system associated with precise estimation of the nitrate application rate is required to increase irrigation water and nitrate use efficiency and to minimize nitrate leaching to groundwater as well.

Water and solute transport models can be used to simulate water and fertilizer distribution within the field soil considering different fertilizer application rates and various design aspects for the irrigation system. The effect of the duration and the amount of water and fertilizer application on root fertilizer uptake and the potential of groundwater contamination risk can easily understand by using numerical models [4]. Therefore, numerical models are considered appropriate tools to design drip fertigation systems. Among many numerical models, the HYDRUS2D/3D is considered the most widely used to simulate water and solute transport in soil under different irrigation methods and practices [21, 22]. Many researchers have shown that the HYDRUS-2D/3D model is a suitable 
software to simulate water flow and fertilizer transport under different irrigation systems and fertigation strategies (e.g., $[2,6,12,14,16,18,23,25])$. Water and fertilizer transport were simulated using HYDRUS-2D/3D under subsurface trickle irrigation systems considering different fertigation strategies in bare soil. They revealed that the application of nitrate at the beginning of the irrigation cycle might reduce the risk of nitrate leaching in highly permeable coarse-textured soil. They also found that the simulation of nitrate movement using HYDRUS-2D/3D was close to the measured value from the field [6]. HYDRUS-2D/3D was used to evaluate nitrate leaching for grape, tomato, citrus and strawberry under four different irrigation systems (surface drip emitter, surface drip tape, subsurface drip tape, and micro-sprinkler) in four different soil types (loam, sandy loam, silty clay, and anisotropic clay). They demonstrated that the total seasonal leaching was the biggest for surface drip tape irrigation system and the smallest for the subsurface drip tape irrigation system. Also, the deep percolation was the highest for coarsetextured soil and lowest for fine-textured soil [12]. HYDRUS-2D/3D was used to evaluate the nitrogen $(\mathrm{N})$ uptake and leaching using urea-ammonium-nitrate fertilizers for DI and SDI systems. They found that $\mathrm{N}$ use efficiency was about 50 to $65 \%$ for DI and 44 to $47 \%$ for SDI [14]. Simulation was conducted using HYDRUS2D/3D to evaluate nitrate leaching for an experimental onion field under DI considering different discharge rates. They found that the amount of nitrogen leaching out from the root zone increases as the emitter discharge increases [2]. According to the above, it seems that the effect of initial soil moisture content $\left(\theta_{\mathrm{i}}\right)$ on nitrate distribution and its leaching under DI and SDI did not catch the researchers' attention so far. Therefore, the current work will focus on (1) the effect of irrigation systems (i.e., DI and SDI) and soil hydraulic properties on nitrate distribution and leaching out from the soil domain and (2) the effect of the $\theta_{\mathrm{i}}$ value on nitrate distribution, leaching below the simulation domain, and taken up by plant roots.

\section{MATERAILS AND METHODS}

The simulation of nitrate distribution under DI and SDI of the tomato crop in sand, sandy loam, and loamy sand soils was conducted using the HYDRUS-2D/3D model. The effect of soil hydraulic properties and $\theta_{i}$ was also considered during simulations. The HYDRUS-2D/3D model can simulate the movement of water, solute, and heat in 2- or 3-dimensional variably saturated porous media. The HYDRUS-2D/3D model uses the Galerkin finite element method to solve the modified form of the Richards equation [17], which includes sink term to consider water uptake by plant roots during simulating water flow. The model solves the Fickian-based advection-dispersion equation for solute transport [15]. The transport equations contain a ratio of non-linear nonequilibrium reactions between the solid and liquid phases and two first-order degradation reactions. For more details of the HYDRUS code and its application, see [22].

The DI and SDI systems were arranged to have the same characteristics; the spacing between drip lines was $140 \mathrm{~cm}$, one drip line per plant row, the spacing between emitter along drip line was set equal to $35 \mathrm{~cm}$, and the emitter flow rate was $1 \mathrm{~L} \mathrm{~h}^{-1}$. The simulation domain was rectangular with $100 \mathrm{~cm}$ deep and $70 \mathrm{~cm}$ wide. In SDI system, the emitter depth was at $10 \mathrm{~cm}$ and $20 \mathrm{~cm}$ below the soil surface (figure 1). Unstructured triangular mesh with 3421 and 3307 2D elements was used to spatially discretize the simulation domain for the DI and SDI, respectively with smaller size mesh elements at the surface and close to the emitter.

During simulations, sand, loamy sand, and sandy loam soils representing three typical agricultural soil types in Egypt were considered. The hydraulic parameters of each type of soil are shown in table 1 . These parameters were taken as in [1] where the same field area was considered in the current study.

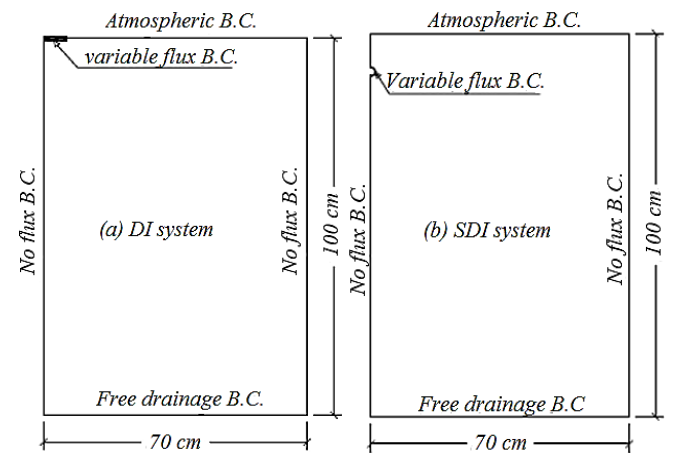

Figure 1: Simulation domain for the investigated DI and SDI systems

Table 1: Hydraulic parameters for the different soil types used in simulations

\begin{tabular}{|c|c|c|c|}
\hline Soil type & Sand & $\begin{array}{c}\text { Loamy } \\
\text { sand }\end{array}$ & $\begin{array}{c}\text { Sandy } \\
\text { loam }\end{array}$ \\
\hline$\theta_{\mathrm{r}}\left(\mathrm{m}^{3} \mathrm{~m}^{-3}\right)$ & 0.024 & 0.074 & 0.038 \\
\hline$\theta_{\mathrm{s}}\left(\mathrm{m}^{3} \mathrm{~m}^{-3}\right)$ & 0.447 & 0.453 & 0.486 \\
\hline$a$ & 0.124 & 0.045 & 0.025 \\
\hline $\mathrm{N}$ & 1.87 & 1.72 & 172 \\
\hline $\mathrm{K}_{\mathrm{s}}\left(\mathrm{cm} \mathrm{d}^{-1}\right)$ & 878.20 & 288.5 & 194.06 \\
\hline$l$ & 0.50 & 0.50 & 0.50 \\
\hline
\end{tabular}

$\theta_{\mathrm{r}}$ : residual water content

$\theta_{\mathrm{s}}$ : saturated water content

$\mathrm{K}_{\mathrm{s}}$ : saturated hydraulic conductivity

$\alpha$ : inverse of the air-entry value

$\mathrm{n}$ : pore-size distribution index

$l$ : pore-connectivity parameter 
The initial soil moisture content values assumed according to Eqn. (1) with same effective saturation $\left(\theta_{\mathrm{e}}\right)$ for all soil types:

$$
\theta_{e}=\frac{\theta-\theta_{r}}{\theta_{s}-\theta_{r}}
$$

where $\theta$ is the volumetric soil moisture content and equal to $\theta_{\mathrm{i}}$ at $\mathrm{t}=0$. The values of $\theta_{\mathrm{e}}$ assumed to be $(0.25$ and $0.33 \mathrm{~m}^{3} \mathrm{~m}^{-3}$ ) to investigate the effect of $\theta_{\mathrm{i}}$ on the nitrate distribution, nitrate leaching out from soil domain, and nitrate taken up by plant roots [19]. $\theta_{\mathrm{i}}$ was assumed uniform within the simulation domain. The values of $\theta_{\mathrm{i}}$ used in the simulation are listed in table 2.

It's worth mentioning that the simulation domain was assumed to be free of fertilizers at the beginning of simulations.

Table 2: Values of initial soil moisture content $\left(\mathrm{m}^{3} \mathrm{~m}^{-3}\right)$

\begin{tabular}{|c|c|c|}
\hline Soil type & $\boldsymbol{\theta}_{\mathbf{i} 1}$ & $\boldsymbol{\theta}_{\mathbf{i} 2}$ \\
\hline Sand & 0.13 & 0.164 \\
\hline Loamy sand & 0.169 & 0.199 \\
\hline Sandy loam & 0.15 & 0.186 \\
\hline
\end{tabular}

Determination of the dispersion tensor components requires knowledge of the molecular diffusion coefficient of the solute in free water $\mathrm{D}_{\mathrm{o}}$ and the longitudinal and transversal dispersivities ( $\varepsilon_{\mathrm{L}}$ and $\varepsilon_{\mathrm{t}}$ respectively). Molecular diffusion for nitrate in solution at $25^{\circ} \mathrm{C}$ was set equal to $1.902 \times 10^{-5} \mathrm{~cm}^{2} \mathrm{~s}^{-1}$ to mimic nitrate diffusion [8, 20]. The $\varepsilon_{\mathrm{L}}$ was set equal to one-tenth of the simulation domain depth while the $\varepsilon$ t was set equal to $0.1 \varepsilon_{\mathrm{L}}[3,7]$.

The boundary conditions (BC) along the domain edges should be set before model execution. Figure 1 shows the imposed BC assumed during the simulation of DI and SDI systems. Due to symmetry and as the simulation domain was made large enough, the vertical sides of the simulation domain were assigned as zero flux BC. As the water table is located $1.50 \mathrm{~m}$ below the soil surface, the bottom boundary was considered as free drainage $\mathrm{BC}$. The top boundary was set as atmospheric BC that allows for crop evapotranspiration $\left(\mathrm{ET}_{\mathrm{c}}\right)$ along the whole length of the upper boundary of simulation domain in the case of SDI while it changed to variable flux $\mathrm{BC}$ in the location of the emitter only in the case of DI. The $\mathrm{ET}_{\mathrm{c}}$ value was taken constant and equal to $0.75 \mathrm{~cm}$ day-1 [19]. Although the HYDRUS-2D/3D model required separating the $\mathrm{ET}_{\mathrm{c}}$ rate to evaporation $(\mathrm{E})$ and transpiration $(\mathrm{T}), \mathrm{T}$ was set equal to $\mathrm{ET}_{\mathrm{c}}$ while $\mathrm{E}$ was assumed to be zero during the simulation period. The simulation was conducted during the midgrowth season of tomato crop at which the surface area of land was approximately covered by tomato leaves (i.e., crop canopy). Thereby, the $\mathrm{E}$ is very low and can be neglected. A constant flux of 68.57 and $109.14 \mathrm{~cm} \mathrm{~d}^{-1}$ was used at the emitter location during the application of water in the case of the DI and SDI, respectively. When casing irrigation, these fluxes were converted to no flux boundary condition. As nitrate was assumed to be applied with irrigation water, third-type Cauchy $\mathrm{BC}$ was set at the top edge of the simulation domain.

Nitrate was added to the tomato crop during the irrigation event according to the agricultural bulletin of tomato issued by the Egyptian Ministry of Agriculture. The total amount of nitrate added through the simulation period was $200 \mathrm{~kg} \mathrm{ha}^{-1}$ and nitrate was added twice a week. Nitrate was applied continuously with irrigation water where the irrigation period lasted $7.35 \mathrm{hr}$. Although nitrate was applied twice per week, irrigation was assumed to be applied every alternate day.

Due to the HYDRUS-2D/3D model does not consider root growth and due to the lack of information about the root distribution under the entire growing season of the tomato crop, only the mid-growth stage was considered during simulation. The total simulation period was 40 days (mid-growth stage). The Vrugt's model was used to prescribe root parameters [24]. The following parameters of Vrugt's model were used as input for the HYDRUS2D/3D model: $Z_{\mathrm{m}}=100 \mathrm{~cm}, \mathrm{X}_{\mathrm{m}}=70 \mathrm{~cm}, \mathrm{z}^{*}=25 \mathrm{~cm}, \mathrm{x}^{*}=$ $0, \mathrm{P}_{\mathrm{z}}=1$, and $\mathrm{P}_{\mathrm{x}}=1$. The effect of water stress reduction was considered using Feddes et al.'s model with the following parameters: $\mathrm{P}_{\mathrm{o}}=-1 \mathrm{~cm}, \mathrm{P}_{\mathrm{opt}}=-2 \mathrm{~cm}, \mathrm{P}_{2 \mathrm{H}}=-800$ $\mathrm{cm}, \mathrm{P}_{2 \mathrm{~L}}=-1500 \mathrm{~cm}, \mathrm{P}_{3}=-8000, \mathrm{r}_{2 \mathrm{H}}=0.10 \mathrm{~cm} \mathrm{~d}^{-1}$, and $\mathrm{r}_{2 \mathrm{~L}}=$ $0.10 \mathrm{~cm} \mathrm{~d}^{-1}$ [11]. Table 3 shows the different scenarios used in the current study.

Table 3: Simulation scenarios

\begin{tabular}{|c|c|c|c|}
\hline $\begin{array}{c}\text { Scenario } \\
\text { number }\end{array}$ & Soil type & Irrigation system & $\theta_{\mathrm{i}}\left(\mathbf{m}^{3} \mathbf{m}^{-3}\right)$ \\
\hline 1 & Sand & DI & 0.13 \\
\hline 2 & Sand & DI & 0.164 \\
\hline 3 & Sand & $\begin{array}{l}\text { SDI with emitter } \\
\text { at depth } 10 \mathrm{~cm}\end{array}$ & 0.13 \\
\hline 4 & Sand & $\begin{array}{l}\text { SDI with emitter } \\
\text { at depth } 10 \mathrm{~cm}\end{array}$ & 0.164 \\
\hline 5 & Sand & $\begin{array}{l}\text { SDI with emitter } \\
\text { at depth } 20 \mathrm{~cm}\end{array}$ & 0.13 \\
\hline 6 & Sand & $\begin{array}{l}\text { SDI with emitter } \\
\text { at depth } 20 \mathrm{~cm}\end{array}$ & 0.164 \\
\hline 7 & $\begin{array}{l}\text { Loamy } \\
\text { Sand }\end{array}$ & DI & 0.169 \\
\hline 8 & $\begin{array}{l}\text { Loamy } \\
\text { sand }\end{array}$ & DI & 0.199 \\
\hline 9 & $\begin{array}{l}\text { Loamy } \\
\text { Sand }\end{array}$ & $\begin{array}{l}\text { SDI with emitter } \\
\text { at depth } 10 \mathrm{~cm}\end{array}$ & 0.169 \\
\hline 10 & $\begin{array}{l}\text { Loamy } \\
\text { sand }\end{array}$ & $\begin{array}{l}\text { SDI with emitter } \\
\text { at depth } 10 \mathrm{~cm}\end{array}$ & 0.199 \\
\hline 11 & $\begin{array}{l}\text { Loamy } \\
\text { Sand }\end{array}$ & $\begin{array}{l}\text { SDI with emitter } \\
\text { at depth } 20 \mathrm{~cm}\end{array}$ & 0.169 \\
\hline 12 & $\begin{array}{l}\text { Loamy } \\
\text { sand }\end{array}$ & $\begin{array}{l}\text { SDI with emitter } \\
\text { at depth } 20 \mathrm{~cm}\end{array}$ & 0.199 \\
\hline
\end{tabular}




\begin{tabular}{|c|c|c|c|}
\hline 13 & $\begin{array}{l}\text { Sandy } \\
\text { loam }\end{array}$ & DI & 0.15 \\
\hline 14 & $\begin{array}{c}\text { Sandy } \\
\text { loam }\end{array}$ & DI & 0.185 \\
\hline 15 & $\begin{array}{l}\text { Sandy } \\
\text { loam }\end{array}$ & $\begin{array}{l}\text { SDI with emitter } \\
\text { at depth } 10 \mathrm{~cm}\end{array}$ & 0.15 \\
\hline 16 & $\begin{array}{l}\text { Sandy } \\
\text { loam }\end{array}$ & $\begin{array}{l}\text { SDI with emitter } \\
\text { at depth } 10 \mathrm{~cm}\end{array}$ & 0.185 \\
\hline 17 & $\begin{array}{l}\text { Sandy } \\
\text { loam }\end{array}$ & $\begin{array}{l}\text { SDI with emitter } \\
\text { at depth } 20 \mathrm{~cm}\end{array}$ & 0.15 \\
\hline 18 & $\begin{array}{l}\text { Sandy } \\
\text { loam }\end{array}$ & $\begin{array}{l}\text { SDI with emitter } \\
\text { at depth } 20 \mathrm{~cm}\end{array}$ & 0.185 \\
\hline
\end{tabular}

\section{RESULTS AND DISCUSSION}

\subsection{Nitrate distribution}

In all simulation scenarios, nitrate concentration patterns have the same trend. During each fertigation event, nitrate starts to concentrate near the emitter at the beginning of fertigation event and reaches to its highest concentration immediately at the end of fertigation event due to nitrate injection. After casing the fertigation event, nitrate concentration decreased due to the redistribution processes and nitrate root uptake. This decline is continued during the period of irrigation events without fertigation due to nitrate movement with irrigation water and root nitrate uptake. As mentioned before, irrigation was applied every alternate day while nitrate fertigation was twice per week. Figure 2 visualizes the progress in nitrate distribution within the simulation domain for sand soil under DI system for various days during the simulation period. The figure shows that at the beginning of the simulation, nitrate starts to concentrate near the emitter and this action was continued with increasing in nitrate concentrations till $t=$ 0.31 days (i.e., the end of the first fertigation event). After that, total nitrate concentration decreased within the simulation domain. This decline was also continued during and after the second irrigation event (from $t=2$ to 4 days) as no fertilizer was applied during the second irrigation event. Nitrate concentration starts again to increase during the second fertigation event (i.e., third irrigation event; from $\mathrm{t}=4$ to 4.31 days). The same trend (successive decrease and increase) occurred during the remaining simulation period.

\subsubsection{Effect of soil type on nitrate distribution}

Figure 3 shows the spatial distribution of nitrate through the simulation domain at the end of the first fertigation event and at the end of the simulation period for scenarios 1, 7, and 13. It was shown that soil type (i.e., soil hydraulic properties) had a significant impact on nitrate distribution in the simulation domain. Nitrate moved down to depths 100,87 , and $84 \mathrm{~cm}$ below the soil surface in sand, loamy sand, and sandy loam, respectively. The figure shows that nitrate moved deepest in sandy soil than in loamy sand and sandy loam soils. This might be due to the low holding capacity of the coarse-textured soil. Nitrate moved laterally to the distance of 50,62 , and $65 \mathrm{~cm}$ at the soil surface in sand, loamy sand, and sandy loam, respectively. The large lateral extension in sandy loam soil was due to the limited infiltration capacity in sandy loam as compared to loamy sand and sandy soils. The same trend happened in the case of SDI with shallow and deep emitter depths.

\subsubsection{Effect of irrigation system on nitrate distribution}

Figure 4 shows the spatial distribution of nitrate in loamy sand soil at the end of the first fertigation event and at the end of the simulation period for scenario 7, 9, and 11.The figure shows that the distribution of nitrate depends mainly on the irrigation system. Nitrate moved downward into loamy sand soil to a depth of 87,77 , and $91 \mathrm{~cm}$ in the case of DI and SDI with 10 and $20 \mathrm{~cm}$ emitter depths respectively. As expected, the downward movement of nitrate increased as the emitter depth increased in the case of SDI. The lowest vertical component of nitrate distribution bulb occurred in SDI with $10 \mathrm{~cm}$ emitter depth as compared to DI and SDI with an emitter depth of $20 \mathrm{~cm}$. This can be attributed to that nitrate was applied effectively in the zone of maximum root density during SDI with shallow emitter depth. Thus, the potential of groundwater contamination risk with the leached nitrate is higher in the case of SDI with deeper emitter and DI as compared to the SDI with a shallower emitter. The same results were obtained for the other soil types (results not shown).

\subsubsection{Effect of initial soil moisture content on nitrate distribution}

Figure 5 displays the nitrate distribution within the simulation domain at the end of the simulation period for scenarios 1-18. The figure shows that $\theta_{\mathrm{i}}$ had a significant effect on the vertical component of nitrate distribution bulb. It increased as initial soil moisture content increased. This increase may be due to the less pore space available which hold applied water and nitrate in soil with higher $\theta_{\mathrm{i}}$. For both DI and SDI with shallow and deep emitter depths in sandy soil, the vertical component of nitrate distribution bulb reached to the lower edge of the simulation domain. However, in loamy sand with DI, the vertical component of nitrate distribution bulb was $87 \mathrm{~cm}$ and $90 \mathrm{~cm}$ at $\theta_{\mathrm{i}}=$ 0.169 and $0.199 \mathrm{~m}^{3} \mathrm{~m}^{-3}$ respectively. In SDI with shallow emitter depth, It was $77 \mathrm{~cm}$ and $80 \mathrm{~cm}$ at $\theta_{\mathrm{i}}=0.169$ and $0.199 \mathrm{~m}^{3} \mathrm{~m}^{-3}$ respectively, while it was 87 and $91 \mathrm{~cm}$ in the case of SDI with deep emitter depth. In sandy loam soil with DI, nitrate moved down to a depth of $84 \mathrm{~cm}$ and 88 

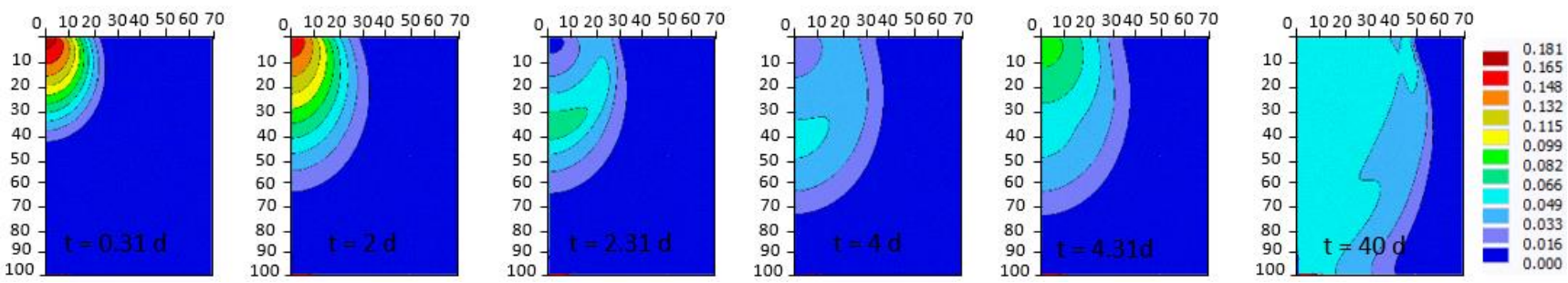

Figure 2: Spatial distribution of nitrate in sand soil under the DI system for $t=0.31$ days (end of the first fertigation/irrigation event, $t=2$ days (the beginning of the second irrigation event), $t=2.31$ days(the end of second irrigation event), $t=4$ days (the beginning of the third irrigation/second fertigation event, $t=4.31$ days (the end of the third irrigation/second fertigation event), and $\mathbf{t}=\mathbf{4 0}$ days (the end of simulation period; units $\mathrm{mg} \mathrm{cm}^{-3}$ ).
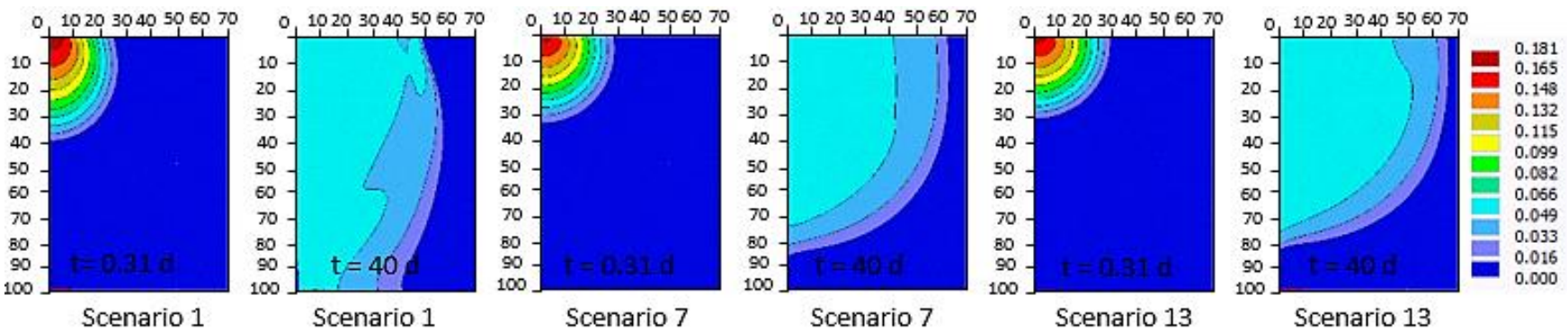

Figure 3: Spatial distribution of nitrate at the end of the first fertigation event and at the end of the simulation period (scenario 1: sand, scenario 7: loamy sand, and scenario 13: sandy loam); units $\mathrm{mg} \mathrm{cm}^{-3}$.
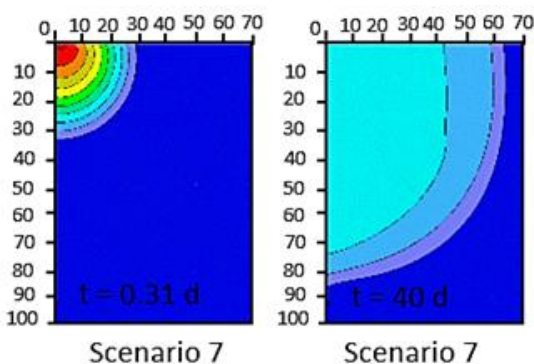

Scenario 7

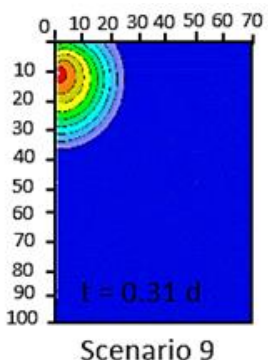

Scenario 9

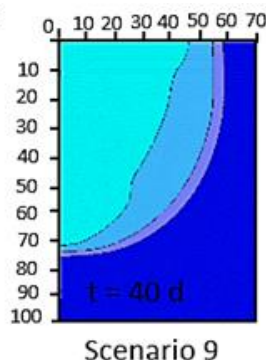

Scenario 9

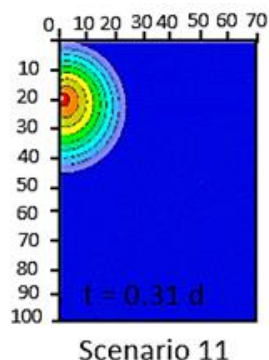

Scenario 11

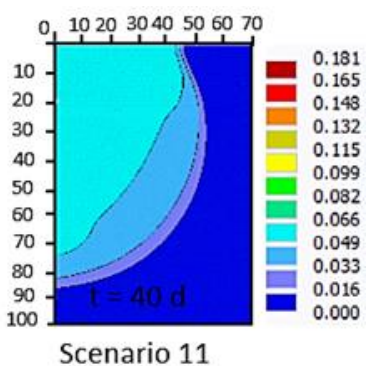

Scenario 11

Figure 4: Spatial distribution of nitrate at the end of the first fertigation event and at the end of the simulation period for loamy sand soil (scenario 7: DI system, scenario 9: SDI system with emitter at depth $10 \mathrm{~cm}$, and scenario 11: SDI system with emitter at depth $20 \mathrm{~cm}$ ); units $\mathrm{mg} \mathrm{cm}^{-3}$.

$\mathrm{cm}$ at $\theta_{\mathrm{i}}=0.15$ and $0.185 \mathrm{~m}^{3} \mathrm{~m}^{-3}$ respectively. In the SDI with $10 \mathrm{~cm}$ emitter depth, it moved down to a depth of 74 $\mathrm{cm}$ and $78 \mathrm{~cm}$ at $\theta_{\mathrm{i}}=0.15$ and $0.185 \mathrm{~m}^{3} \mathrm{~m}^{-3}$ respectively, while it reached depths of $82 \mathrm{~cm}$ and $88 \mathrm{~cm}$ under SDI with $20 \mathrm{~cm}$ emitter depth. Initial soil moisture content plays a great role in the amount of fertilizer that reaches to deep soil layer. Thus, measuring and monitoring of $\theta \mathrm{i}$ are desired for better irrigation and fertigation management.

\subsection{Nitrate leaching}

Table 4 shows the percentages of nitrate leached below the bottom edge of the simulation domain as a fraction of the total nitrate added to the soil domain. The result reveals that the amount of nitrate leached from the soil domain was the highest for sandy soil and lowest for sandy loam soil. This is because of the low water holding capacity of sand as compared to loamy sand and sandy loam soil. In addition, the gravity force governs the rapid downward movement of water with nitrate in the sandy soil. The limited infiltration capacity of fine-textured soil particles (sandy loam soil) increases the soil retention of water and nitrate making the fine-textured soil less susceptible to leaching losses. The capillary force dominates the flow in fine-textured soil. Also, the results show that the SDI with shallow emitter depth had the lowest leaching percentage as compared to DI and SDI system with deep emitter depth. This can be attributed to that the nitrate was applied in the zone of maximum root density as the emitter was 
located close to this zone. Thereby nitrate could effectively be taken up by plant roots. Initial soil moisture content had

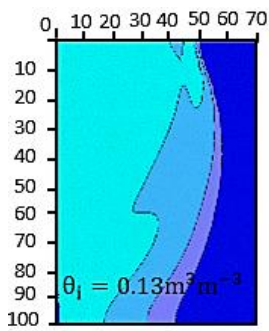

Scenario 1

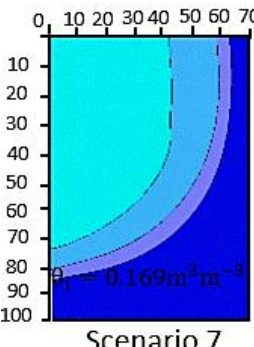

Scenario 7

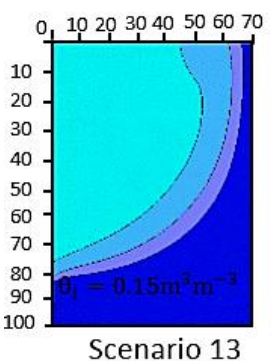

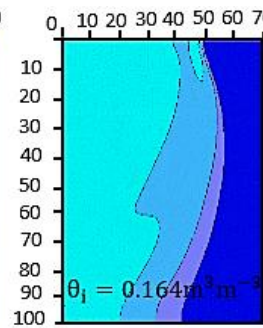

Scenario 2

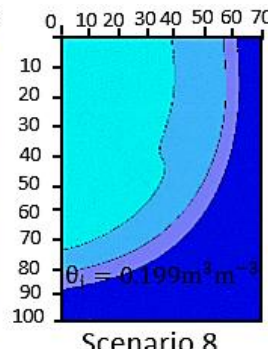

Scenario 8

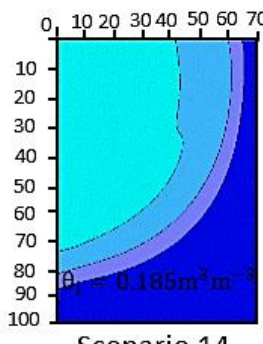

Scenario 14

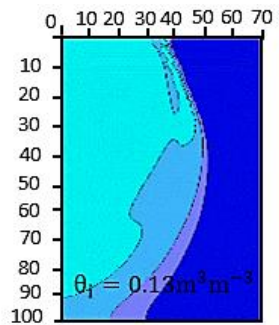

Scenario 3

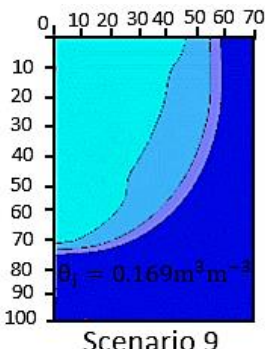

Scenario 9

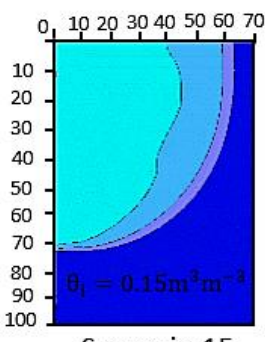

Scenario 15

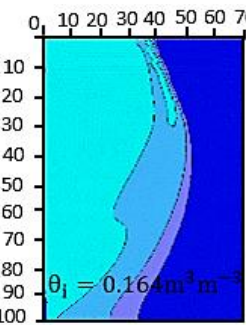

Scenario 4

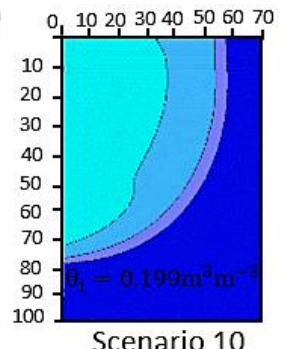

Scenario 10

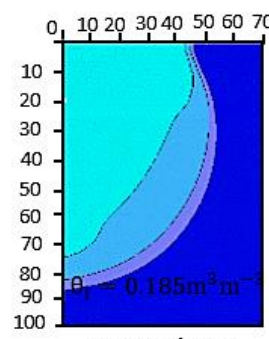

Scenario 16

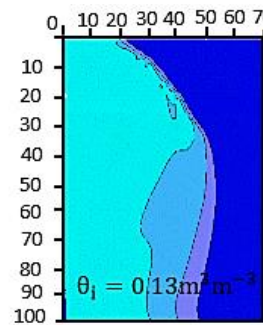

Scenario 5

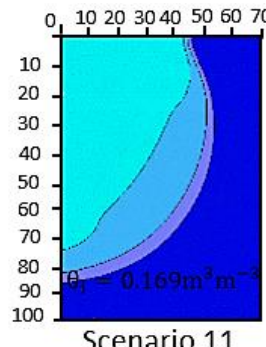

Scenario 11

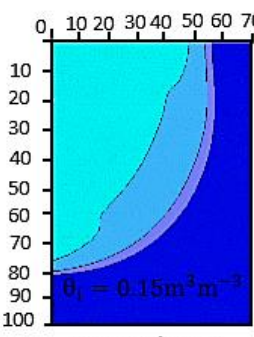

Scenario 17

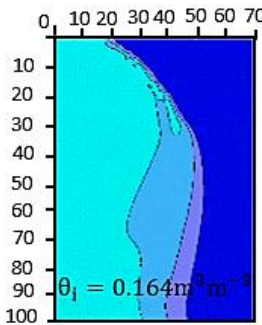

Scenario 6
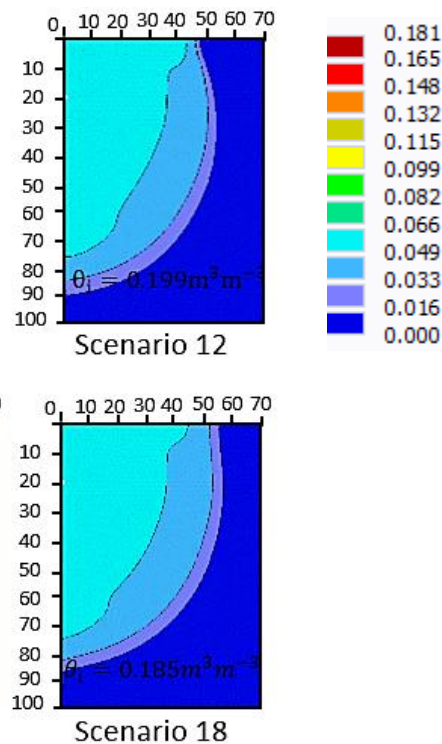

Figure 5: Spatial distribution of nitrate at the end of the first fertigation event and at the end of the simulation period under DI, SDI with emitter at depths $10 \mathrm{~cm}$, and $20 \mathrm{~cm}$ (scenarios 1 to 6 for sand; scenarios 7 to 12 for loamy sand; and scenarios 13 to 18 for sandy loam)); units $\mathrm{mg} \mathrm{cm}^{-3}$.

Table 4: The percentages of nitrate leached as a fraction of the total nitrate added.

\begin{tabular}{|c|c|c|c|c|}
\hline Soil type & $\theta_{\mathbf{i}}$ & DI & $\begin{array}{c}\text { SDI with emitter } \\
\text { depth of } \mathbf{1 0} \mathbf{~ c m}\end{array}$ & $\begin{array}{c}\text { SDI with emitter } \\
\text { depth of 20 cm }\end{array}$ \\
\hline Sand & 0.13 & 1.46 & 0.58 & 4.09 \\
\hline Sand & 0.164 & 2.33 & 1.49 & 5.77 \\
\hline Loamy sand & 0.169 & 0.02 & $4.90 \mathrm{E}-04$ & 0.04 \\
\hline Loamy sand & 0.199 & 0.16 & 0.05 & 0.32 \\
\hline Sandy loam & 0.15 & 0 & 0 & 0 \\
\hline Sandy loam & 0.185 & 0 & 0 & 0 \\
\hline
\end{tabular}

deep soil layers and to assess the potential of groundwater contamination risk.

a significant effect on the amount of nitrate leaching out from simulation domain. As $\theta \mathrm{i}$ increases, the amount of nitrate leaching out from simulation domain increases. This result supports the importance of monitoring soil moisture status before applying nitrate fertilizer to precisely estimate how much nitrate will percolate to the

\section{3. $\quad$ Nitrate uptake}

Table 5 shows the percentages of nitrate uptake by plant roots as a fraction of the total nitrate added from the soil 
domain (nitrate use efficiency). The result reveals that the amount of nitrate taken up by plant root was the highest for sandy and loamy sand soils in the case of SDI with shallow emitter depth as compared to DI and SDI with deep emitter

Table 5: The percentages of nitrate uptake by plant roots as a fraction of the total nitrate added.

\begin{tabular}{|c|c|c|c|c|}
\hline Soil type & $\theta_{\mathbf{i}}$ & DI & $\begin{array}{c}\text { SDI with emitter at } \\
\text { depth } \mathbf{1 0} \mathbf{~ c m}\end{array}$ & $\begin{array}{c}\text { SDI with emitter at } \\
\text { depth } \mathbf{2 0} \mathbf{~ c m}\end{array}$ \\
\hline Sand & 0.13 & 78.86 & 82.62 & 77.62 \\
\hline Sand & 0.164 & 77.93 & 81.44 & 75.95 \\
\hline Loamy sand & 0.169 & 74.92 & 79.52 & 79.51 \\
\hline Loamy sand & 0.199 & 74.29 & 79.40 & 78.29 \\
\hline Sandy loam & 0.15 & 72.89 & 77.14 & 78.33 \\
\hline Sandy loam & 0.185 & 71.66 & 76.10 & 76.52 \\
\hline
\end{tabular}

and plants with shallow roots. Results also showed higher

depth. This was attributed to that the nitrate was applied in the zone of maximum root density as the emitter was located close to this zone. Thereby, nitrate could effectively be taken up by plant roots. On the other hand, the amount of nitrate taken up by plant root was the highest for sandy loam in the case of SDI as compared to DI regardless the location of the emitter. The result also shows that there was a decrease in the amount of nitrate taken up by plant roots with the increase in the initial soil moisture content. This can be attributed to that the soil was prone to reach its field capacity faster in the case of high $\theta_{\mathrm{i}}$ as compared to low $\theta_{\mathrm{i}}$. Consequently, in the case of high $\theta_{\mathrm{i}}$, some of the nitrate associated with irrigation water rapidly percolate to the deeper soil layer without exploited by plant roots

\section{CONCLUSION}

The present study investigated the effect of soil hydraulic properties and initial soil moisture content on nitrate distribution within the simulation domain, the amount of nitrate that can percolate to the groundwater, and nitrate taken up by plant roots for DI and SDI systems with emitter at depths $10 \mathrm{~cm}$ and $20 \mathrm{~cm}$ for tomato plants. Simulation results showed that nitrate leaching is significantly affected by the soil type. Sandy soils were more susceptible to the risk of nitrate leaching as compared to loamy sand and sandy loam soils. In addition, nitrate leaching below the simulation domain was affected by the location of emitters. The SDI with shallow emitter depth (near the root zone)has a lower amount of nitrate leached as compared to other drip irrigation systems where water and nitrate are effectively injected to the zone of maximum root density. Consequently, the SDI with shallow emitter depth is recommended as compared to SDI with deep emitter depth to reduce the potential groundwater contamination risk especially in sandy soil $\theta_{\mathrm{i}}$ leads to augment in the percentage of nitrate leaching

out from the simulation domain. Therefore, measuring and monitoring of $\theta_{\mathrm{i}}$ are desired for better irrigation and fertigation management. Also, for a good estimation of the potential risk of groundwater contamination.

At the end, we believe that the results of the current study will enhance the awareness of Egyptian farmers toward drip fertigation systems and how to increase nitrate use efficiency.

\section{REFERENCES}

[1] Abou Lila, T.S., Berndtsson,R., Persson, M., Somaida, M., El_Kiki, M., \& Hamed, Y. "Numerical evaluation of subsurface trickle irrigation with brackish water'. Irrig Sci. 31, 1125-1137, 2013.

[2] Ajdary, K., Singh, D.K., Singh, A.K., \& Khanna, M. "Modeling of nitrogen leaching from experimental onion field under drip fertigation". Agric. Water Manage. 89, 15-28, 2007.

[3] Anderson, M.P. "Movement of contaminants in groundwater: groundwater transport-advection and dispersion. In Groundwater Contamination. Studiesin Geophysics". NationalAcademy: Washington, DC; 37-45, 1984.

[4] Antonopoulos, V.Z. "Simulation of water and nitrogen balances of irrigation and fertilized corn-crop soil". J. Irri. Drain. Eng. 127(2): 77-83, 2001.

[5] Bar-Yosef, B. Advances in fertigation. Adv. Agron. 65, 1-75, 1999.

[6] Cote, C.M., Bristow, K.L., Ford, E.J., Verburg, K., \& Keating, B. "Measurement of water and solute movement in large undisturbed soil cores: analysis of Macknade and Bundaderg date". CSIRO land and water. Technical Report 07/2001, 2001.

[7] Cote, C.M., Bristow, K.L., Charlesworth, P.B., Cook, F.J., \& Thorburn, P.J. "Analysis of soil wetting and 
solute transport in subsurface trickle irrigation". Irrig. Sci. 22, 143-156, 2003.

[8] David, R. Lide, ed., CRC Handbook of Chemistry and Physics, Internet Version 2005, <http://www.hbcpnetbase.com>, CRC Press, Boca Raton, FL, 2005.

[9] Falivene, S., Goodwin, I., Williams, D., \& Boland, A. Introduction to Open Hydroponics. In: NPSI Fact sheet. National Program for Sustainable Irrigation, 2005.

[10] FAO. Fertilizer use by crop in Egypt. Land and Plant Nutrition Management Service, Land and Water Development Division. Roma, Italy, 2005.

[11] Feddes, R.A., Kowalik, P.J., \& Zaradny, H. "Simulation of field water use and crop yield". John Wiley \& Sons, New York, 1978.

[12] Gardenas, A.I., Hopman, J.W., Hanson, B.R., \& Simunek, J. "Two-dimensional modeling of nitrate leahing for various fertigation scenarios under microirrigation". Agric. Water Manage. 74 (3), 219-242, 2005.

[13] Hanson, B., Schwankl, L., Granttan, S., \& Prichard, T. Drip irrigation for row crops: Water management handbook series (publication 93-05). University of California, Davis, CA, 1996.

[14] Hanson, B.R., Simunek, J., \& Hopmans, J.W. "Evaluation of urea-ammonium-nitrate fertigation with drip irrigation using numerical modeling”. Agric. Water Manage. 86, 102-113, 2006.

[15] Hillel, D. Environmental Soil Physics. Academic Press, Inc. 525 B Street, Suit 1900, San Diego, CA 92101-4495, 1998.

[16] Raij, I., Simunek, J., Ben-Gal, A., \& Lazarovitch, N. "Water flow and multicomponent solute transport in drip irrigated lysimeters: Experiments and modeling”. Water Res. Res., 52, 6557-6574, 2016.

[17] Richards, L.A. Capillarity conduction of liquids through porous media. Physics 1, 318-333, 1931.
[18] Salehi, A.A., Navabian, M., Varaki, M.E., \&Pirmoradian, N. "Evaluation of HYDRUS-2D model to simulate the loss of nitrate in subsurface controlled drainage in a physical model scale of paddy fields". Padd. \& Water Environ, 15(2), 433-442, 2017.

[19] Selim, T., Berndtsson, R., \& Persson, M. "Simulation of soil water and salinity distribution under surface drip irrigation”. Irrig. \& Drain. 62, 352-362, 2013.

[20] Shekofteh, H., Afyuni, M., \& Hajabbasi, M.A. "Modeling of nitrate leaching from a potato field using HYDRUS-2D". Communications in Soil Sci. Plant Analy. 44(20), 2917-2931, 2013.

[21] Simunek, J., Sejna, M. \& van Genuchten, M. Th. The "HYDRUS-2D software package for simulating the wo-dimensional movement of water, heat and multiple solute in variably-saturated media". International Groundwater Modeling Centre, ColoradoSchool of Mines Golden, Co 80401, 1999.

[22] Simunek, J., van Genuchten, M.Th., \& Šejna, M. "Recent Developments and Applications of the HYDRUS Computer Software Packages". Vadose Zone J. doi:10.2136/vzj2016.04.0033, 2016.

[23] Siyal, A.A., Bristow, K.L., \& Simunek, J. "Minimizing nitrogen leaching from furrow irrigation through novel fertilizer placement and soil surface management strategies". Agric. Water Manag. 115, 242-251, 2012.

[24] Vrugt, J.A., van Wijk, M.T., Hopmans, J.W., \& Simunek, J. "Comparison of one, two, and threedimensional root water uptake functions for transient water flow modeling". Water Resour. Res. 37, 2457 2470, 2001.

[25] Zhen W., Jiusheng, L., \& Yanfeng, L. "Simulation of nitrate leaching under varying drip system uniformities and precipitation patterns during the growing season of maize in the North China Plain". Agric. Water Manag. 142, 19-28, 2014. 